\title{
SOME NEW OBSERVATIONS ON FIXED POINT RESULTS IN RECTANGULAR METRIC SPACES WITH APPLICATIONS TO CHEMICAL SCIENCES
}

\author{
Mudasir Younis ${ }^{\mathrm{a}}$, Nicola Fabiano ${ }^{\mathrm{b}}$, Zaid M. Fadail ${ }^{\mathrm{c}}$, \\ Zoran D. Mitrovićd , Stojan N. Radenoviće \\ a University Institute of Technology - RGPV, \\ Department of Applied Mathematics, Bhopal, M.P, India, \\ e-mail: mudasiryouniscuk@gmail.com, \\ ORCID iD: (1) https://orcid.org/0000-0001-5499-4272 \\ ${ }^{b}$ Independent researcher, Rome, Italy, \\ e-mail: nicola.fabiano@gmail.com, \\ ORCID iD: (1)https://orcid.org/0000-0003-1645-2071 \\ c Thamar University, Faculty of Education, \\ Department of Mathematical Science, Thamar, Republic of Yemen, \\ e-mail: zaid.fadail@tu.edu.ye, \\ ORCID iD: (1)https://orcid.org/0000-0003-0899-0056 \\ d University of Banja Luka, Faculty of Electrical Engineering, \\ Banja Luka, Republic of Srpska, Bosnia and Herzegovina, \\ e-mail: zoran.mitrovic@etf.unibl.org, corresponding author, \\ ORCID iD: (Dhttps://orcid.org/0000-0001-9993-9082 \\ e University of Belgrade, Faculty of Mechanical Engineering, \\ Department of Mathematics, Belgrade, Republic of Serbia, \\ e-mail: radens@beotel.rs, \\ ORCID iD: (1)https://orcid.org/ 0000-0001-8254-6688
}

DOI: 10.5937/vojtehg69-29517; https://doi.org/10.5937/vojtehg69-29517

FIELD: Mathematics

ARTICLE TYPE: Original scientific paper

Abstract:

Introduction/purpose: This paper considers, generalizes and improves recent results on fixed points in rectangular metric spaces. The aim of this paper is to provide much simpler and shorter proofs of some new results in rectangular metric spaces.

Methods: Some standard methods from the fixed point theory in generalized metric spaces are used.

Results: The obtained results improve the well-known results in the literature. The new approach has proved that the Picard sequence is Cauchy in rectangular metric spaces. The obtained results are used to prove the existence of solutions 
to some nonlinear problems related to chemical sciences. Finally, an open question is given for generalized contractile mappings in rectangular metric spaces.

Conclusions: New results are given for fixed points in rectangular metric spaces with application to some problems in chemical sciences.

Key words: fixed point, rectangular metric space, contractive map, Green function.

\section{Introduction and Preliminaries}

It is well known that the Banach contraction principle (Banach, 1922) is one of the most important and attractive results in nonlinear analysis and mathematical analysis in general. The whole fixed point theory is a significant subject in different fields: geometry, differential equations, informatics, physics, economics, engineering, and many others. After solutions are guaranteed, numerical methodology is established to obtain the approximated solution. The fixed point of functions depends heavily on considered spaces defined using intuitive axioms. In particular, variants of generalized metric spaces are proposed, e.g. partial metric space, $b$-metric, partial $b$-metric, extended $b$-metric, rectangular metric, rectangular $b$-metric, Gmetric, $\mathrm{G}_{b}$-metric, S-metric, $\mathrm{S}_{b}$-metric, cone metric, cone $b$-metric, fuzzy metric, fuzzy $b$-metric, probabilistic metric, etc. For more details on all variants of generalized metric spaces, see (Budhia et al, 2017), (Collaco \& Silva, 1997).

In this paper, we will discuss some results recently established in (Alsulami et al, 2015) and (Budhia et al, 2017). Firstly, we give the basic notion of a rectangular metric space (g.m.s or RMS by some authors).

Definition 1. Let $X$ be a nonempty set and let $d_{r}: X \times X \rightarrow[0,+\infty)$ satisfy the following conditions: for all $x, y \in X$ and all distinct $u, v \in X$ each of them different from $x$ and $y$.

(i) $d_{r}(x, y)=0$ if and only if $x=y$,

(ii) $d_{r}(x, y)=d_{r}(y, x)$,

(iii) $d_{r}(x, y) \leq d_{r}(x, u)+d_{r}(u, v)+d_{r}(v, y)$ (quadrilateral inequality).

Then the function $d_{r}$ is called a rectangular metric and the pair $\left(X, d_{r}\right)$ is called a rectangular metric space (RMS for short).

Notice that the definitions of convergence and Cauchyness of the sequences in rectangular metric spaces are the same as the ones found in 
the standard metric spaces. Also, a rectangular metric space $\left(X, d_{r}\right)$ is complete if each Cauchy sequence in it is convergent. Samet et al. (Samet et al, 2012) introduced the concept of $\alpha-\psi$-contractive mappings and proved the fixed point theorems for such mappings. In (Karapınar, 2014), Karapinar gave contractive conditions to obtain the existence and uniqueness of a fixed point of $\alpha-\psi$ contraction mappings in rectangular metric spaces. Salimi et al. (Salimi et al, 2013) introduced modified $\alpha-\psi$ contractive mappings and obtained some fixed point theorems in a complete metric space. Alsulami et al. (Alsulami et al, 2015) established some fixed point theorems for $\alpha-\psi$-rational type contractive mappings in a rectangular metric space.

Let $\Psi$ be the family of all functions $\psi:[0,+\infty) \rightarrow[0,+\infty)$ such that $\psi$ is nondecreasing and $\sum_{n=1}^{+\infty} \psi^{n}(t)<+\infty$ for each $t>0$. Obviously, if $\psi \in \Psi$, then $\psi(t)<t$ for each $t>0$.

Definition 2. (Salimi et al, 2013) Let $T$ be a self mapping on a metric space $\left(X, d_{r}\right)$ and let $\alpha, \eta: X \times X \rightarrow[0,+\infty)$ be two functions. It is called an $\alpha$-admissible mapping with respect to $\eta$ if $\alpha(x, y) \geq \eta(x, y)$ implies that $\alpha(T x, T y) \geq \eta(T x, T y)$ for all $x, y \in X$.

If $\eta(x, y)=1$ for all $x, y \in X$, then $T$ is called an $\alpha$-admissible mapping.

It is called a triangular $\alpha$-admissible mapping if for all $x, y, z \in X$ holds: $(\alpha(x, y) \geq 1$ and $\alpha(y, z) \geq 1)$ implies $\alpha(x, z) \geq 1$.

Otherwise, a rectangular metric space $\left(X, d_{r}\right)$ is $\alpha$-regular with respect to $\eta$ if for any sequence in $X$ such that $\alpha\left(x_{n}, x_{n+1}\right) \geq \eta\left(x_{n}, x_{n+1}\right)$ for all $n \in \mathbb{N}$ and $x_{n} \rightarrow x$ as $n \rightarrow+\infty$, then $\alpha\left(x_{n}, x\right) \geq \eta\left(x_{n}, x\right)$.

For more details on a triangular $\alpha$-admissible mapping, see (Karapınar et al, 2013), pages 1 and 2. In this paper, we will use the following result:

Lemma 1. (Karapınar et al, 2013), Lemma 7. Let $T$ be a triangular $\alpha$-admissible mapping. Assume that there exists $x_{0} \in X$ such that $\alpha\left(x_{0}, T x_{0}\right) \geq 1$. Define the sequence $\left\{x_{n}\right\}$ by $x_{n}=T^{n} x_{0}$. Then

$$
\alpha\left(x_{m}, x_{n}\right) \geq 1 \text { for all } m, n \in \mathbb{N} \cup\{0\} \text { with } m<n .
$$

In (Budhia et al, 2017), the authors proved the following result:

Theorem 1. Let $\left(X, d_{r}\right)$ be a Hausdorff and complete rectangular metric space, and let $T: X \rightarrow X$ be an $\alpha$-admissible mapping with respect to 
$\eta$. Assume that there exists a continuous function $\psi \in \Psi$ such that

$$
x, y \in X, \alpha(x, y) \geq \eta(x, y) \text { implies } d_{r}(T x, T y) \leq \psi(M(x, y)),
$$

where

$$
\begin{gathered}
M(x, y)=\max \left\{d_{r}(x, y), d_{r}(x, T x), d_{r}(y, T y), \frac{d_{r}(x, T x) d_{r}(y, T y)}{1+d_{r}(x, y)},\right. \\
\left.\frac{d_{r}(x, T x) d_{r}(y, T y)}{1+d_{r}(T x, T y)}\right\} .
\end{gathered}
$$

Also, suppose that the following assertions hold:

1. there exists $x_{0} \in X$ such that $\alpha\left(x_{0}, T x_{0}\right) \geq \eta\left(x_{0}, T x_{0}\right)$,

2. for all $x, y, z \in X,(\alpha(x, y) \geq \eta(x, y)$ and $\alpha(y, z) \geq \eta(y, z))$ implies $\alpha(x, z) \geq \eta(x, z)$,

3. either $T$ is continuous or $X$ is $\alpha$-regular with respect to $\eta$.

Then $T$ has a periodic point $a \in X$ and if $\alpha(a, T a) \geq \eta(a, T a)$ holds for each periodic point, then $T$ has a fixed point. Moreover, if for all $x, y \in$ $F(T)$, we have $\alpha(x, y) \geq \eta(x, y)$, then the fixed point is unique.

Taking $\eta(x, y)=1$ for $x, y \in X$, the authors obtained the following corollary:

Corollary 1. Let $\left(X, d_{r}\right)$ be a Hausdorff and complete rectangular metric space, and let $T: X \rightarrow X$ be an $\alpha$-admissible mapping. Assume that there exists a continuous function $\psi \in \Psi$ such that

$$
x, y \in X, \alpha(x, y) \geq 1 \text { implies } d_{r}(T x, T y) \leq \psi(M(x, y))
$$

where

$$
\begin{gathered}
M(x, y)=\max \left\{d_{r}(x, y), d_{r}(x, T x), d_{r}(y, T y), \frac{d_{r}(x, T x) d_{r}(y, T y)}{1+d_{r}(x, y)},\right. \\
\left.\frac{d_{r}(x, T x) d_{r}(y, T y)}{1+d_{r}(T x, T y)}\right\} .
\end{gathered}
$$

Also, suppose that the following assertions hold: 
1. there exists $x_{0} \in X$ such that $\alpha\left(x_{0}, T x_{0}\right) \geq 1$,

2. for all $x, y, z \in X(\alpha(x, y) \geq 1$ and $\alpha(y, z) \geq 1)$ implies $\alpha(x, z) \geq 1$,

3. either $T$ is continuous or $\left(X, d_{r}\right)$ is $\alpha$-regular.

Then $T$ has a periodic point $a \in X$ and if $\alpha(a, T a) \geq 1$ holds $T$ has a fixed point. Moreover, if for all $x, y \in F(T)$, we have $\alpha(x, y) \geq 1$, then the fixed point is unique.

Further, taking $\alpha(x, y)=1$ for $x, y \in X$ authors obtained the following corollary:

Corollary 2. Let $\left(X, d_{r}\right)$ be a Hausdorff and complete rectangular metric space, and let $T: X \rightarrow X$ be an $\alpha$-admissible mapping. Assume that there exists a continuous function $\psi \in \Psi$ such that

$$
x, y \in X, 1 \geq \eta(x, y) \text { implies } d_{r}(T x, T y) \leq \psi(M(x, y))
$$

where

$$
\begin{gathered}
M(x, y)=\max \left\{d_{r}(x, y), d_{r}(x, T x), d_{r}(y, T y), \frac{d_{r}(x, T x) d_{r}(y, T y)}{1+d_{r}(x, y)},\right. \\
\left.\frac{d_{r}(x, T x) d_{r}(y, T y)}{1+d_{r}(T x, T y)}\right\} .
\end{gathered}
$$

Also, suppose that the following assertions hold:

1. there exists $x_{0} \in X$ such that $1 \geq \eta\left(x_{0}, T x_{0}\right)$,

2. for all $x, y, z \in X(1 \geq \eta(x, y)$ and $1 \geq \eta(y, z))$ implies $1 \geq \eta(x, z)$,

For $\psi(t)=k t, 0<k<1$ then the authors obtained

Corollary 3. Let $\left(X, d_{r}\right)$ be a Hausdorff and complete rectangular metric space, and let $T: X \rightarrow X$ be an $\alpha$-admissible mapping with respect to $\eta$. Assume that

$$
x, y \in X, \alpha(x, y) \geq \eta(x, y) \text { implies } d_{r}(T x, T y) \leq k M(x, y),
$$

where

$$
M(x, y)=\max \left\{d_{r}(x, y), d_{r}(x, T x), d_{r}(y, T y), \frac{d_{r}(x, T x) d_{r}(y, T y)}{1+d_{r}(x, y)},\right.
$$




$$
\left.\frac{d_{r}(x, T x) d_{r}(y, T y)}{1+d_{r}(T x, T y)}\right\}
$$

Also, suppose that the following assertions hold:

1. there exists $x_{0} \in X$ such that $\alpha\left(x_{0}, T x_{0}\right) \geq \eta\left(x_{0}, T x_{0}\right)$,

2. for all $x, y, z \in X(\alpha(x, y) \geq \eta(x, y)$ and $\alpha(y, z) \geq \eta(y, z))$ implies $\alpha(x, z) \geq \eta(x, z)$,

3. either $T$ is continuous or $\left(X, d_{r}\right)$ is $\alpha$-regular.

Then $T$ has a periodic point $a \in X$ and if $\alpha(a, T a) \geq \eta(a, T a)$ holds, $T$ has a fixed point. Moreover, if for all $x, y \in F(T)$, we have $\alpha(x, y) \geq$ $\eta(x, y)$, then the fixed point is unique.

The following two lemmas are a rectangular metric space modification of a result which is well known in the metric space, see, e.g, (Radenović et al, 2012), Lemma 2.1. Many known proofs of fixed point results in rectangular metric spaces become much more straightforward and shorter using both lemmas. Also, in the proofs of the main results in this paper, we will use both lemmas:

Lemma 2. (Kadelburg \& Radenović, 2014a), (Kadelburg \& Radenović, 2014b) Let $\left(X, d_{r}\right)$ be a rectangular metric space and let $\left\{x_{n}\right\}$ be a sequence in it with distinct elements $\left(x_{n} \neq x_{m}\right.$ for $\left.n \neq m\right)$. Suppose that $d_{r}\left(x_{n}, x_{n+1}\right)$ and $d_{r}\left(x_{n}, x_{n+2}\right)$ tend to 0 as $n \rightarrow+\infty$ and that $\left\{x_{n}\right\}$ is not a Cauchy sequence. Then there exists $\varepsilon>0$ and two sequences $\{m(k)\}$ and $\{n(k)\}$ of positive integers such that $n(k)>m(k)>k$ and the following sequences tend to $\varepsilon$ as $k \rightarrow+\infty$ :

$$
\begin{gathered}
\left\{d_{r}\left(x_{n(k)}, x_{m(k)}\right)\right\},\left\{d_{r}\left(x_{n(k)+1}, x_{m(k)}\right)\right\},\left\{d_{r}\left(x_{n(k)}, x_{m(k)-1}\right)\right\}, \\
\left\{d_{r}\left(x_{n(k)+1}, x_{m(k)-1}\right)\right\},\left\{d_{r}\left(x_{n(k)+1}, x_{m(k)+1}\right)\right\} .
\end{gathered}
$$

Lemma 3. Let $\left\{x_{n+1}\right\}_{n \in \mathbb{N} \cup\{0\}}=\left\{T x_{n}\right\}_{n \in \mathbb{N} \cup\{0\}}=\left\{T^{n} x_{0}\right\}_{n \in \mathbb{N} \cup\{0\}}, T^{0} x_{0}=$ $x_{0}$ be a Picard sequence in a rectangular metric space $\left(X, d_{r}\right)$ induced by the mapping $T: X \rightarrow X$ and the initial point $x_{0} \in X$. If $d_{r}\left(x_{n}, x_{n+1}\right)<$ $d_{r}\left(x_{n-1}, x_{n}\right)$ for all $n \in \mathbb{N}$ then $x_{n} \neq x_{m}$ whenever $n \neq m$. 
Proof. Let $x_{n}=x_{m}$ for some $n, m \in \mathbb{N}$ with $n<m$. Then $x_{n+1}=T x_{n}=$ $T x_{m}=x_{m+1}$. Further, we get

$$
d_{r}\left(x_{n}, x_{n+1}\right)=d_{r}\left(x_{m}, x_{m+1}\right)<d_{r}\left(x_{m-1}, x_{m}\right)<\ldots<d_{r}\left(x_{n}, x_{n+1}\right),
$$

which is a contradiction.

In some proofs, we will also use the following interesting as well as significant result in the context of rectangular metric spaces:

Proposition 1. (Kirk \& Shahzad, 2014), Proposition 3. Suppose that $\left\{q_{n}\right\}$ is a Cauchy sequence in a rectangular metric space $\left(X, d_{r}\right)$ and suppose $\lim _{n \rightarrow+\infty} d_{r}\left(q_{n}, q\right)=0$. Then $\lim _{n \rightarrow+\infty} d_{r}\left(q_{n}, p\right)=d_{r}(q, p)$ for all $p \in X$. In particular, $\left\{q_{n}\right\}$ does not converge to $p$ if $p \neq q$.

\section{Main results}

In this section, we generalize and improve Theorem 2 and all its corollaries. The obtained generalizations extend the result in several directions. Namely, we will use only one function $\alpha: X \times X \rightarrow[0,+\infty)$ instead of two $\alpha$ and $\eta$ as in (Budhia et al, 2017), Definition 2.3. and Definition 3.1. This is possible according to the (Mohammadi \& Rezapour, 2013), Page 2, after Theorem 1.2. Note that we assume neither that the rectangular metric space is Hausdorff, nor that the mapping $d_{r}$ is continuous.

The authors (Alsulami et al, 2015), page 6, line 6+, say that the sequence $\left\{x_{n}\right\}$ in a rectangular metric space $\left(X, d_{r}\right)$ is a Cauchy if $\lim _{n \rightarrow+\infty} d_{r}\left(x_{n}, x_{n+k}\right)=0$, for all $k \in \mathbb{N}$. However, it is well know that this claim is dubious. Therefore, we also improve the proof that the sequence $\left\{x_{n}\right\}$ is Cauchy

Our first new result in this paper is the following:

Theorem 2. Let $\left(X, d_{r}\right)$ be a complete rectangular metric space and let $T$ : $X \rightarrow X$ be a triangular $\alpha$-admissible mapping. Assume that there exists continuous function $\psi \in \Psi$ such that

$$
x, y \in X, \alpha(x, y) \geq 1 \text { implies } d_{r}(T x, T y) \leq \psi(M(x, y)),
$$

where

$$
M(x, y)=\max \left\{d_{r}(x, y), d_{r}(x, T x), d_{r}(y, T y), \frac{d_{r}(x, T x) d_{r}(y, T y)}{1+d_{r}(x, y)},\right.
$$




$$
\left.\frac{d_{r}(x, T x) d_{r}(y, T y)}{1+d_{r}(T x, T y)}\right\}
$$

Also, suppose that the following assertions hold:

1. there exists $x_{0} \in X$ such that $\alpha\left(x_{0}, T x_{0}\right) \geq 1$,

2. either $T$ is continuous or $(X, d) \alpha$-regular.

Then $T$ has a fixed point. Moreover, if

$$
\text { for all } x, y \in F(T) \text { implies } \alpha(x, y) \geq 1 \text {, }
$$

then the fixed point is unique.

Proof. Given $x_{0} \in X$ such that

$$
\alpha\left(x_{0}, T x_{0}\right) \geq 1 .
$$

Define a sequence $\left\{x_{n}\right\}$ in $X$ by $x_{n}=T x_{n-1}=T^{n} x_{0}$ for all $n \in \mathbb{N}$. If $x_{k+1}=x_{k}$ for some $k \in \mathbb{N}$, then $T x_{k}=x_{k}$, i.e., $x_{k}$ is a fixed point of $T$ and the proof is finished. From now on, suppose that $x_{n} \neq x_{n+1}$ for all $n \in \mathbb{N} \cup\{0\}$. Using (2) and the fact that $T$ is an $\alpha$-admissible mapping, we have

$$
\alpha\left(x_{1}, x_{2}\right)=\alpha\left(T x_{0}, T x_{1}\right) \geq 1 .
$$

By induction, we get

$$
\alpha\left(x_{n}, x_{n+1}\right) \geq 1 \text { for all } n \in \mathbb{N} \cup\{0\} .
$$

In the first step, we will show that the sequence $\left\{d_{r}\left(x_{n}, x_{n+1}\right)\right\}$ is nonincreasing and $d_{r}\left(x_{n}, x_{n+1}\right) \rightarrow 0$ as $n \rightarrow+\infty$. From (1), recall that

$$
d_{r}\left(x_{n}, x_{n+1}\right)=d_{r}\left(T x_{n-1}, T x_{n}\right) \leq \psi\left(M\left(x_{n-1}, x_{n}\right)\right),
$$

where

$$
\begin{gathered}
M\left(x_{n-1}, x_{n}\right)=\max \left\{d_{r}\left(x_{n-1}, x_{n}\right), d_{r}\left(x_{n-1}, x_{n}\right), d_{r}\left(x_{n}, x_{n+1}\right),\right. \\
\left.\frac{d_{r}\left(x_{n-1}, x_{n}\right) d_{r}\left(x_{n}, x_{n+1}\right)}{1+d_{r}\left(x_{n-1}, x_{n}\right)}, \frac{d_{r}\left(x_{n-1}, x_{n}\right) d_{r}\left(x_{n}, x_{n+1}\right)}{1+d_{r}\left(x_{n}, x_{n+1}\right)}\right\} \\
\leq \max \left\{d_{r}\left(x_{n-1}, x_{n}\right), d_{r}\left(x_{n}, x_{n+1}\right)\right\} .
\end{gathered}
$$


Now from (3) follows

$$
d_{r}\left(x_{n}, x_{n+1}\right) \leq \psi\left(\max \left\{d_{r}\left(x_{n-1}, x_{n}\right), d_{r}\left(x_{n}, x_{n+1}\right)\right\}\right) .
$$

If $\max \left\{d_{r}\left(x_{n-1}, x_{n}\right), d_{r}\left(x_{n}, x_{n+1}\right)\right\}=d_{r}\left(x_{n}, x_{n+1}\right)$, we get a contradiction. Indeed, (4) implies

$$
d_{r}\left(x_{n}, x_{n+1}\right) \leq \psi\left(d_{r}\left(x_{n}, x_{n+1}\right)\right)<d_{r}\left(x_{n}, x_{n+1}\right) .
$$

Therefore, we get that $d_{r}\left(x_{n}, x_{n+1}\right)<d_{r}\left(x_{n-1}, x_{n}\right)$. This means that there exists $\lim _{n \rightarrow+\infty} d_{r}\left(x_{n}, x_{n+1}\right)=d_{r}^{*} \geq 0$. If $d_{r}^{*}>0$, then from (3) follows

$$
\begin{gathered}
d_{r}^{*} \leq \psi\left(\max \left\{d_{r}^{*}, d_{r}^{*}, d_{r}^{*}, \frac{d_{r}^{*^{2}}}{1+d_{r}^{*}}, \frac{d_{r}^{*^{2}}}{1+d_{r}^{*}}\right\}\right) \\
\leq \psi\left(\max \left\{d_{r}^{*}, d_{r}^{*}\right\}\right)<d_{r}^{*},
\end{gathered}
$$

which is a contradiction. Hence $\lim _{n \rightarrow+\infty} d_{r}\left(x_{n}, x_{n+1}\right)=0$.

Further, we will also show that $\lim _{n \rightarrow+\infty} d_{r}\left(x_{n}, x_{n+2}\right)=0$. Firstly, we have that $\alpha\left(x_{n-1}, x_{n}\right) \geq 1$, i.e., $\alpha\left(x_{n-1}, x_{n+1}\right) \geq 1$, because $T$ is a triangular $\alpha$-admissible mapping. Therefore,

$$
d_{r}\left(x_{n}, x_{n+2}\right)=d_{r}\left(T x_{n-1}, T x_{n+1}\right) \leq \psi\left(M\left(x_{n-1}, x_{n+1}\right)\right),
$$

where

$$
\begin{gathered}
M\left(x_{n-1}, x_{n+1}\right)=\max \left\{d_{r}\left(x_{n-1}, x_{n+1}\right), d_{r}\left(x_{n-1}, x_{n}\right), d_{r}\left(x_{n+1}, x_{n+2}\right),\right. \\
\left.\frac{d_{r}\left(x_{n-1}, x_{n}\right) d_{r}\left(x_{n+1}, x_{n+2}\right)}{1+d_{r}\left(x_{n-1}, x_{n+1}\right)}, \frac{d_{r}\left(x_{n-1}, x_{n}\right) d_{r}\left(x_{n+1}, x_{n+2}\right)}{1+d_{r}\left(x_{n}, x_{n+2}\right)}\right\} .
\end{gathered}
$$

Since $\frac{d_{r}\left(x_{n-1}, x_{n}\right) d_{r}\left(x_{n+1}, x_{n+2}\right)}{1+d_{r}\left(x_{n-1}, x_{n+1}\right)} \leq d_{r}\left(x_{n-1}, x_{n}\right) d_{r}\left(x_{n+1}, x_{n+2}\right)$ and $\frac{d_{r}\left(x_{n-1}, x_{n}\right) d_{r}\left(x_{n+1}, x_{n+2}\right)}{1+d_{r}\left(x_{n}, x_{n+2}\right)} \leq d_{r}\left(x_{n-1}, x_{n}\right) d_{r}\left(x_{n+1}, x_{n+2}\right)$ we get that

$$
\begin{gathered}
M\left(x_{n-1}, x_{n+1}\right) \leq \max \left\{d_{r}\left(x_{n-1}, x_{n+1}\right), d_{r}\left(x_{n-1}, x_{n}\right),\right. \\
\left.d_{r}\left(x_{n+1}, x_{n+2}\right), d_{r}\left(x_{n-1}, x_{n}\right) d_{r}\left(x_{n+1}, x_{n+2}\right)\right\}
\end{gathered}
$$

that is,

$$
M\left(x_{n-1}, x_{n+1}\right) \leq \max \left\{d_{r}\left(x_{n-1}, x_{n+1}\right), d_{r}\left(x_{n-1}, x_{n}\right), d_{r}^{2}\left(x_{n-1}, x_{n}\right)\right\}
$$




$$
\leq \max \left\{d_{r}\left(x_{n-1}, x_{n+1}\right), d_{r}\left(x_{n-1}, x_{n}\right)\right\} .
$$

The last relation follows from the fact that $d_{r}\left(x_{n-1}, x_{n}\right) \rightarrow 0$ as $n \rightarrow+\infty$. Hence, for some $n_{1} \in \mathbb{N}$, we have that

$$
d_{r}\left(x_{n}, x_{n+2}\right) \leq \max \left\{d_{r}\left(x_{n-1}, x_{n+1}\right), d_{r}\left(x_{n-1}, x_{n}\right)\right\},
$$

whenever $n \geq n_{1}$. Since, $d_{r}\left(x_{n-1}, x_{n}\right) \rightarrow 0$ as $n \rightarrow+\infty$ it is not hard to check that also $d_{r}\left(x_{n}, x_{n+2}\right) \rightarrow 0$ as $n \rightarrow+\infty$.

In order to prove that the sequence $\left\{x_{n}\right\}$ is a Cauchy one, we use Lemma 6. Namely, since according to Lemma $1, \alpha\left(x_{n(k)}, x_{m(k)}\right) \geq 1$ if $m(k)<$ $n(k)$, then, by putting in (1) $x=x_{n(k)}, y=x_{m(k)}$, we obtain

$$
d_{r}\left(x_{n(k)+1}, x_{m(k)+1}\right) \leq \psi\left(M\left(x_{n(k)}, x_{m(k)}\right)\right),
$$

where

$$
\begin{gathered}
M\left(x_{n(k)}, x_{m(k)}\right)= \\
=\max \left\{d_{r}\left(x_{n(k)}, x_{m(k)}\right), d_{r}\left(x_{n(k)}, x_{n(k)+1}\right), d_{r}\left(x_{m(k)}, x_{m(k)+1}\right),\right. \\
\left.\frac{d_{r}\left(x_{n(k)}, x_{n(k)+1}\right) d_{r}\left(x_{m(k)}, x_{m(k)+1}\right)}{1+d_{r}\left(x_{n(k)}, x_{m(k)}\right)}, \frac{d_{r}\left(x_{n(k)}, x_{n(k)+1}\right) d_{r}\left(x_{m(k)}, x_{m(k)+1}\right)}{1+d_{r}\left(x_{n(k)+1}, x_{m(k)+1}\right)}\right\} \\
\underset{k \rightarrow+\infty}{\rightarrow} M\left(x_{n(k)}, x_{m(k)}\right)=\max \left\{\varepsilon, 0,0, \frac{0 \cdot 0}{1+\varepsilon}, \frac{0 \cdot 0}{1+\varepsilon}\right\}=\varepsilon .
\end{gathered}
$$

Now, taking in (5) the limit as $k \rightarrow+\infty$ follows

$$
\varepsilon \leq \psi(\varepsilon)<\varepsilon,
$$

which is a contradiction. The sequence $\left\{x_{n}\right\}$ is hence a Cauchy one. Since $\left(X, d_{r}\right)$ is a complete rectangular metric space, there exists a point $x^{*} \in X$ such that $x_{n} \rightarrow x^{*}$ as $n \rightarrow+\infty$. If $T$ is continuous, we get that $x_{n+1}=T x_{n} \rightarrow$ $T x^{*}$ as $n \rightarrow+\infty$. Let $T x^{*} \neq x^{*}$. Since $d_{r}\left(x_{n}, x_{n+1}\right)<d_{r}\left(x_{n-1}, x_{n}\right)$ for all $n \in \mathbb{N} \cup\{0\}$, then, according to Lemma 7 , we have that all $x_{n}$ are distinct. Therefore, there exists $n_{2} \in \mathbb{N}$ such that $x^{*}, T x^{*} \notin\left\{x_{n}\right\}_{n \geq n_{2}}$. Further, by (iii) follows:

$$
d_{r}\left(x^{*}, T x^{*}\right) \leq d_{r}\left(x^{*}, x_{n}\right)+d_{r}\left(x_{n}, x_{n+1}\right)+d_{r}\left(x_{n+1}, T x^{*}\right),
$$

whenever $n \geq n_{2}$, taking the limit, we obtain $d_{r}\left(x^{*}, T x^{*}\right)=0$, i.e. $x^{*}=T x^{*}$, which is a contradiction. 
In the case that $\left(X, d_{r}\right)$ is $\alpha$-regular, we get the following: Since $\alpha\left(x_{n}, x^{*}\right) \geq 1$ for all $n \in \mathbb{N}$, then from (1) follows

$$
d_{r}\left(T x_{n}, T x^{*}\right) \leq \psi\left(M\left(x_{n}, x^{*}\right)\right)
$$

where

$$
\begin{gathered}
M\left(x_{n}, x^{*}\right)=\max \left\{d_{r}\left(x_{n}, x^{*}\right), d_{r}\left(x_{n}, x_{n+1}\right), d_{r}\left(x^{*}, T x^{*}\right),\right. \\
\left.\frac{d_{r}\left(x_{n}, x_{n+1}\right) d_{r}\left(x^{*}, T x^{*}\right)}{1+d_{r}\left(x_{n}, x^{*}\right)}, \frac{d_{r}\left(x_{n}, x_{n+1}\right) d_{r}\left(x^{*}, T x^{*}\right)}{1+d_{r}\left(x_{n+1}, T x^{*}\right)}\right\} \underset{n \rightarrow+\infty}{\rightarrow} d_{r}\left(x^{*}, T x^{*}\right) .
\end{gathered}
$$

By taking in (6) the limit as $n \rightarrow+\infty$ and by using Proposition 8 and the continuity of the function $\psi$, we get $d_{r}\left(x^{*}, T x^{*}\right) \leq \psi\left(d_{r}\left(x^{*}, T x^{*}\right)\right)<d_{r}\left(x^{*}, T x^{*}\right)$ if $x^{*} \neq T x^{*}$., which is a contradiction. Hence, $x^{*}$ is a fixed point of $T$.

Now, we show that the fixed point is unique if $\alpha(x, y) \geq 1$ whenever $x, y \in F(T)$. Indeed, in this case, by contractive condition (1), for such possible fixed points $x, y$ we have

$$
d_{r}(x, y)=d_{r}(T x, T y) \leq \psi(M(x, y))
$$

where

$$
\begin{aligned}
& M(x, y)= \max \left\{d_{r}(x, y), d_{r}(x, T x), d_{r}(y, T y), \frac{d_{r}(x, T x) d_{r}(y, T y)}{1+d_{r}(x, y)},\right. \\
&\left.\frac{d_{r}(x, T x) d_{r}(y, T y)}{1+d_{r}(T x, T y)}\right\} \\
&=\max \left\{d_{r}(x, y), 0,0, \frac{0 \cdot 0}{1+0}, \frac{0 \cdot 0}{1+0}\right\}=d_{r}(x, y) .
\end{aligned}
$$

Hence, (7) becomes

$$
d_{r}(x, y) \leq \psi\left(d_{r}(x, y)\right)<d_{r}(x, y)
$$

which is a contradiction. The proof of Theorem 9 is complete.

Remark 1. In the proof of case 2 on Page 96, the authors used the fact that the rectangular metric $d_{r}$ (see condition (3.12)) is continuous, which is not given in the formulation of (Budhia et al, 2017), Theorem 3.2. 
By putting in (1) instead of $M(x, y)$, one of the following sets

$$
\begin{aligned}
& \left\{d_{r}(x, y)\right\}, \max \left\{d_{r}(x, y), d_{r}(x, T x), d_{r}(y, T y)\right\}, \\
& \max \left\{\frac{d_{r}(x, T x) d_{r}(y, T y)}{1+d_{r}(x, y)}, \frac{d_{r}(x, T x) d_{r}(y, T y)}{1+d_{r}(T x, T y)}\right\},
\end{aligned}
$$

immediately follows as a consequence of Theorem 9.

Corollary 4. Let $\left(X, d_{r}\right)$ be a complete rectangular metric space and let $T$ : $X \rightarrow X$ be a triangular $\alpha$-admissible mapping. Assume that there exists a continuous function $\psi \in \Psi$ such that

$$
x, y \in X, \alpha(x, y) \geq 1 \text { implies } d_{r}(T x, T y) \leq \psi\left(d_{r}(x, y)\right) .
$$

Also, suppose that the following assertions hold:

1. there exists $x_{0} \in X$ such that $\alpha\left(x_{0}, T x_{0}\right) \geq 1$,

2. either $T$ is continuous or $\left(X, d_{r}\right)$ is $\alpha$-regular.

Then $T$ has a fixed point. Moreover, if for all $x, y \in F(T)$, we have $\alpha(x, y) \geq 1$, then the fixed point is unique.

Corollary 5. Let $\left(X, d_{r}\right)$ be a complete rectangular metric space and let $T$ : $X \rightarrow X$ be a triangular $\alpha$-admissible mapping. Assume that there exists a continuous function $\psi \in \Psi$ such that for $x, y \in X$,

$$
\alpha(x, y) \geq 1 \text { yields } d_{r}(T x, T y) \leq \psi\left(\max \left\{d_{r}(x, y), d_{r}(x, T x), d_{r}(y, T y)\right\}\right)
$$

Also, suppose that the following assertions hold:

1. there exists $x_{0} \in X$ such that $\alpha\left(x_{0}, T x_{0}\right) \geq 1$,

2. either $T$ is continuous or $\left(X, d_{r}\right)$ is $\alpha$-regular.

Then $T$ has a fixed point. Moreover, if for all $x, y \in F(T)$, we have $\alpha(x, y) \geq 1$, then the fixed point is unique.

Corollary 6. Let $\left(X, d_{r}\right)$ be a complete rectangular metric space and let $T$ : $X \rightarrow X$ be a triangular $\alpha$-admissible mapping. Assume that there exists a 
continuous function $\psi \in \Psi$ such that for $x, y \in X, \alpha(x, y) \geq 1$

yields $d_{r}(T x, T y) \leq \psi\left(\max \left\{\frac{d_{r}(x, T x) d_{r}(y, T y)}{1+d_{r}(x, y)}, \frac{d_{r}(x, T x) d_{r}(y, T y)}{1+d_{r}(T x, T y)}\right\}\right)$.

Also, suppose that the following assertions hold:

1. there exists $x_{0} \in X$ such that $\alpha\left(x_{0}, T x_{0}\right) \geq 1$,

2. either $T$ is continuous or $\left(X, d_{r}\right)$ is $\alpha$-regular.

Then $T$ has a fixed point. Moreover, if for all $x, y \in F(T)$, we have $\alpha(x, y) \geq 1$, then the fixed point is unique.

In the book (Ćirić, 2003), Ćirić collected various contractive mappings in the usual metric spaces, see also (Rhoades, 1977) and (Collaco \& Silva, 1997). The next three contractive conditions are well known in the existing literature:

- Ćirić 1: Ćirić's generalized contraction of first order: there exists $k_{1} \in$ $[0,1)$ such that for all $x, y \in X$ holds:

$d(T x, T y) \leq k_{1} \max \left\{d(x, y), \frac{d(x, T x)+d(y, T y)}{2}, \frac{d(x, T y)+d(y, T x)}{2}\right\}$.

- Ćirić 2: Ćirić's generalized contraction of second order: there exists $k_{2} \in[0,1)$ such that for all $x, y \in X$ holds:

$$
d(T x, T y) \leq k_{2} \max \left\{d(x, y), d(x, T x), d(y, T y), \frac{d(x, T y)+d(y, T x)}{2}\right\} .
$$

In both cases, $(X, d)$ is a metric space, $T: X \rightarrow X$ is a given selfmapping of the set $X$.

In (Ćirić, 2003), Ćirić introduced one of the most generalized contractive conditions (so-called quasicontraction) in the context of a metric space as follows:

- Ćirić 3: The self-mapping $T: X \rightarrow X$ on a metric space $(X, d)$ is called a quasicontraction (in the sense of Ćirić) if there exists $k_{3} \in[0,1)$ such that for all $x, y \in X$ holds:

$$
d(T x, T y) \leq k_{3} \max \{d(x, y), d(x, T x), d(y, T y), d(x, T y), d(y, T x)\} .
$$


Since,

$$
\frac{d(x, T x)+d(y, T y)}{2} \leq \max \{d(x, T x), d(y, T y)\}
$$

and

$$
\frac{d(x, T y)+d(y, T x)}{2} \leq \max \{d(x, T y), d(y, T x)\}
$$

it follows that (11) implies (12) and (12) implies (13).

In (Ćirić, 2003), Ćirić proved the following result:

Theorem 3. Each quasicontraction $T$ on a complete metric space $(X, d)$ has a unique fixed point (say) $z$. Moreover, for all $x \in X$, the sequence $\left\{T^{n} x\right\}_{n=0}^{+\infty}, T^{0} x=x$ converges to the fixed point $z$ as $n \rightarrow+\infty$.

Now we can formulate the following notion and one open question:

Definition 3. Let $\left(X, d_{r}\right)$ be a rectangular metric space and let $\alpha: X \times X \rightarrow$ $[0,+\infty)$ be a mapping. The mapping $T: X \rightarrow X$ is said to be a modified triangular $\alpha$-admissible mapping if there exists a continuous function $\psi \in \Psi$ such that

$$
x, y \in X, \alpha(x, y) \geq 1 \text { implies } d_{r}(T x, T y) \leq \psi(M(x, y)),
$$

where $M(x, y)$ is one of the sets:

$$
\begin{gathered}
\max \left\{d_{r}(x, y), \frac{d_{r}(x, T x)+d_{r}(y, T y)}{2}, \frac{d_{r}(x, T y)+d_{r}(y, T x)}{2}\right\} \\
\max \left\{d_{r}(x, y), d_{r}(x, T x), d_{r}(y, T y), \frac{d_{r}(x, T y)+d_{r}(y, T x)}{2}\right\} \\
\max \left\{d_{r}(x, y), d_{r}(x, T x), d_{r}(y, T y), d_{r}(x, T y), d_{r}(y, T x)\right\} .
\end{gathered}
$$

\section{An open problem}

A suggestion for further research - it is logical to ask the following question:

Problem 0.1. Let $T$ be a modified triangular $\alpha$-admissible mapping defined on a complete rectangular metric space $\left(X, d_{r}\right)$ such that $T$ is continuous or $\left(X, d_{r}\right)$ is $\alpha$-regular. Show that $T$ has a fixed point. 


\section{Applications}

In this section, we will focus on the applicability of the obtained results.

\section{An application to chemical sciences}

Consider a diffusing substance placed in an absorbing medium between parallel walls such that $\delta_{1}, \delta_{2}$ are the stipulated concentrations at walls. Moreover, let $\Omega(r)$ be the given source density and $\Xi(r)$ be the known absorption coefficient. Then the concentration $\varkappa(r)$ of the substance under the aforementioned hypothesis governs the following boundary value problem

$$
\left\{\begin{array}{c}
-\varkappa^{\prime \prime}+\Xi(r) \varkappa=\Omega(r) \quad ; r \in[0,1]=I \\
\varkappa(0)=\delta_{1}, \varkappa(0)=\delta_{2},
\end{array}\right.
$$

Problem (1) is equivalent to the succeeding integral equation

$$
\varkappa(r)=\delta_{1}+\left(\delta_{2}-\delta_{1}\right) r+\int_{0}^{1} \Theta(r, \varpi)(\Omega(\varpi)-\Xi(\varpi) \varkappa(\varpi)), \quad r \in[0,1],
$$

where $\Theta(r, \varpi):[0,1] \times \mathbb{R} \rightarrow \mathbb{R}$ is the Green's function which is continuous and is given by

$$
\Theta(r, \varpi)= \begin{cases}r(1-\varpi) & 0 \leq r \leq \varpi \leq 1 \\ \varpi(1-r) & 0 \leq \varpi \leq r \leq 1\end{cases}
$$

Suppose that $C(I, \mathbb{R})=X$ is the space of all real valued continuous functions defined on $I$ and let $X$ be endowed with the rectangular $b$-metric $d_{r}$ defined by

$$
d_{r}\left(\varkappa, \varkappa^{*}\right)=\left\|\left(\varkappa-\varkappa^{*}\right)\right\|
$$

where $\|\varkappa\|=\sup \{|\varkappa(r)|: r \in I\}$. Obviously $\left(X, d_{r}\right)$ is a complete rectangular metric space.

Let the operator $\Xi: X \rightarrow X$ be defined by

$$
\Xi \varkappa(r)=\varkappa(r)=\delta_{1}+\left(\delta_{2}-\delta_{1}\right) r+\int_{0}^{1} \Theta(r, \varpi)(\Omega(\varpi)-\Xi(\varpi) \varkappa(\varpi)) .
$$

Then $\varkappa^{*}$ is a unique solution of (2) if and only if it is a fixed point of $\Xi$. The subsequent Theorem is furnished for the assertion of the existence of a fixed point of $\Xi$. 
Theorem 4. Consider problem (2) and suppose that there exists $\wp>0$ and a continuous function $\Xi(\varpi): I \rightarrow \mathbb{R}$ such that the following assertion holds: $\alpha\left(\varkappa(\varpi), \varkappa^{*}(\varpi)\right) \geq 1 \Longrightarrow 0 \leq\left|\Xi(\varpi) \varkappa(\varpi)-\Xi(\varpi) \varkappa^{*}(\varpi)\right| \leq \varkappa^{*}(\varpi)-\varkappa(\varpi)$.

Then the integral equation (2) and, consequently, the boundary value problem (1) governing the concentration of the diffusing substance has a unique solution in $X$.

Proof. Clearly, for $\varkappa \in X$ and $r \in I$, the mapping $\Xi: X \rightarrow X$ is well defined. Also $\Xi$ is triangular $\alpha$-admissible.

$$
\begin{aligned}
& \left|\Xi \varkappa(r)-\Xi \varkappa^{*}(r)\right| \\
& =\mid \int_{0}^{1} \Theta(r, \varpi)(\Omega(\varpi)-\Xi(\varpi) \varkappa(\varpi)) d \varpi-h(r) \\
& -\int_{0}^{1} \Theta(r, \varpi)\left(\Omega(\varpi)-\Xi(\varpi) \varkappa^{*}(\varpi)\right) d \varpi \mid \\
& \leq \int_{0}^{1} \Theta(r, \varpi)\left|(\Omega(\varpi)-\Xi(\varpi) \varkappa(\varpi))-\left(\Omega(\varpi)-\Xi(\varpi) \varkappa^{*}(\varpi)\right)\right| d \varpi \\
& =\int_{0}^{1} \Theta(r, \varpi)\left|\Xi(\varpi) \varkappa(\varpi)-\Xi(\varpi) \varkappa^{*}(\varpi)\right| d \varpi \\
& \leq \int_{0}^{1} \Theta(r, \varpi)\left|\varkappa(\varpi)-\varkappa^{*}(\varpi)\right| d \varpi \\
& \leq \int_{0}^{1} \Theta(r, \varpi)\left\|\left(\varkappa(\varpi)-\varkappa^{*}(\varpi)\right)\right\| d \varpi \\
& \leq\left\|\left(\varkappa-\varkappa^{*}\right)\right\| \sup _{r \in[0,1]} \int_{0}^{1} \Theta(r, \varpi) d \varpi .
\end{aligned}
$$

Since $\int_{0}^{1} \Theta(r, \varpi) d \varpi=\frac{r-r^{2}}{2}$ and so $\sup _{r \in[0,1]} \int_{0}^{1} \Theta(r, \varpi) d \varpi=\frac{1}{8}$.

Hence for all $\varkappa, \varkappa^{*} \in X$, we obtain

$$
d_{r}\left(\Xi \varkappa, \Xi \varkappa^{*}\right) \leq \frac{d_{r}\left(\varkappa, \varkappa^{*}\right)}{8} \leq \frac{M\left(\varkappa, \varkappa^{*}\right)}{8},
$$

where

$$
M\left(\varkappa, \varkappa^{*}\right)=\max \left\{d_{r}\left(\varkappa, \varkappa^{*}\right), d_{r}(\varkappa, T \varkappa), d_{r}\left(\varkappa^{*}, T \varkappa^{*}\right),\right.
$$




$$
\left.\frac{d_{r}(\varkappa, T \varkappa) d_{r}\left(\varkappa^{*}, T \varkappa^{*}\right)}{1+d_{r}\left(\varkappa, \varkappa^{*}\right)}, \frac{d_{r}(\varkappa, T \varkappa) d_{r}\left(\varkappa^{*}, T \varkappa^{*}\right)}{1+d_{r}\left(T \varkappa, T \varkappa^{*}\right)}\right\}
$$

Taking $\psi\left(M\left(\varkappa, \varkappa^{*}\right)\right)=\frac{1}{8}$, we obtain

$$
d_{r}\left(T \varkappa, T \varkappa^{*}\right) \leq \psi\left(M\left(\varkappa, \varkappa^{*}\right)\right)
$$

Hence, all the hypotheses of Theorem 2 are contented. We conclude that $\Xi$ has a unique fixed point $\varkappa$ in $X$, which guarantees that the integral equation (2) has a unique solution and, consequently, the boundary value problem (1) has a unique solution.

Application to a class of integral equations for an unknown function

We present the application of the existence of a fixed point for a generalized contraction to the following class of integral equations for an unknown function $u$ :

$$
u(t)=g(t)+\int_{a}^{b} \chi(t, z) f(z, u(z)) d z, \quad t \in[a, b],
$$

where $f:[a, b] \times \mathbb{R} \rightarrow \mathbb{R}, K:[a, b] \times[a, b] \rightarrow[0, \infty), g:[a, b] \rightarrow \mathbb{R}$ are the given continuous functions.

Let $X$ be the set $C[a, b]$ of real continuous functions defined on $[a, b]$ and let $d_{r}: X \times X \rightarrow[0, \infty)$ be equipped with the metric defined by

$$
d_{r}(u, v)=\sup _{a \leq t \leq b}|u(t)-v(t)| .
$$

One can easily verify that $\left(X, d_{r}\right)$ is a complete rectangular metric space. Let the self map $T: X \rightarrow X$ be defined by

$$
T u(t)=g(t)+\int_{a}^{b} \chi(t, z) f(z, u(z)) d z, \quad t \in[a, b],
$$

then $u$ is a fixed point of $T$ if and only it is a solution of (4). Also, we can easily check that $T$ is triangular $\alpha$-admissible. Now, we formulate the following subsequent theorem to show the existence of a solution of the underlying integral equation. 
Theorem 5. Assume that the following assumptions hold:

(1) $\sup _{a \leq t \leq b} \int_{a}^{b}|\chi(t, z)| d z \leq \frac{1}{b-a}$;

(2) Suppose that for all $x, y \in \mathbb{R}$,

$$
\alpha(x(t), y(t)) \geq 1 \Longrightarrow|f(z, x)-f(z, y)| \leq \frac{1}{2}|x(t)-y(t)| .
$$

Then integral equation (4) has a solution.

Proof. Employing conditions (1) - (2) along with inequality (4), we have

$$
\begin{aligned}
& d_{r}\left(T u_{1}, T u_{2}\right)=\sup _{a \leq t \leq b}\left|T u_{1}(t)-T u_{2}(t)\right| \\
& =\sup _{a \leq t \leq b}\left|g(t)+\int_{a}^{b} \chi(t, z) f\left(z, u_{1}(z)\right) d z-\left(g(t)+\int_{a}^{b} \chi(t, z) f\left(z, u_{2}(z)\right) d z\right)\right| \\
& =\sup _{a \leq t \leq b}\left\{\left|\int_{a}^{b}\left(\chi(t, z) f\left(z, u_{1}(z)\right)-\chi(t, z) f\left(z, u_{2}(z)\right)\right) d z\right|\right\} \\
& \leq \sup _{a \leq t \leq b}\left\{\int_{a}^{b}|\chi(t, z)| d z \cdot \int_{a}^{b}\left|f\left(z, u_{1}(z)\right)-f\left(z, u_{2}(z)\right)\right| d z\right\} \\
& =\left\{\sup _{a \leq t \leq b} \int_{a}^{b}|\chi(t, z)| d z\right\} \cdot\left\{\int_{a}^{b}\left|f\left(z, u_{1}(z)\right)-f\left(z, u_{2}(z)\right)\right| d z\right\} \\
& =\left\{\sup _{a \leq t \leq b} \int_{a}^{b}|\chi(t, z)| d z\right\} \cdot\left\{\int_{a}^{b}\left|f\left(z, u_{1}(z)\right)-f\left(z, u_{2}(z)\right)\right| d z\right\} \\
& \leq\left\{\frac{1}{b-a}\right\} \cdot\left\{\frac{1}{2} \int_{a}^{b}\left|u_{1}(z)-u_{2}(z)\right| d z\right\} \\
& \leq \frac{1}{2(b-a)} \int_{a}^{b} \sup _{a \leq t \leq b}\left|u_{1}(t)-u_{2}(t)\right| d z \\
& =\frac{1}{2} \sup _{a \leq t \leq b}\left|u_{1}(t)-u_{2}(t)\right|
\end{aligned}
$$

i.e $d_{r}\left(T u_{1}, T u_{2}\right)=\frac{1}{2}\left(d_{r}\left(u_{1}, u_{2}\right)\right) \leq \frac{M\left(u_{1}, u_{2}\right)}{2}$. Which amounts to say that

$$
d_{r}\left(T u_{1}, T u_{2}\right) \leq \frac{M\left(u_{1}, u_{2}\right)}{2}
$$

where

$$
M\left(u_{1}, u_{2}\right)=\max \left\{d_{r}\left(u_{1}, u_{2}\right), d_{r}\left(u_{1}, T u_{1}\right), d_{r}\left(u_{2}, T u_{2}\right),\right.
$$




$$
\left.\frac{d_{r}\left(u_{1}, T u_{1}\right) d_{r}\left(u_{2}, T u_{2}\right)}{1+d_{r}\left(u_{1}, u_{2}\right)}, \frac{d_{r}\left(u_{1}, T u_{1}\right) d_{r}\left(u_{2}, T u_{2}\right)}{1+d_{r}\left(T u_{1}, T u_{2}\right)}\right\} .
$$

Taking $\psi\left(M\left(u_{1}, u_{2}\right)\right)=\frac{1}{2}$, the above inequality turns into

$$
d_{r}\left(T u_{1}, T u_{2}\right) \leq \psi\left(M\left(u_{1}, u_{2}\right)\right)
$$

Thus, all the hypotheses Theorem 2 are satisfied and we conclude that $T$ has a unique fixed point $x^{*}$ in $X$, which amounts to say that integral equation (4) has a unique solution which belongs to $X=C[a, b]$.

\section{References}

Alsulami, H.H., Chandok, S., Taoudi, M-A. \& Erhan, I.M. 2015. Some fixed point theorems for $(\alpha, \psi)$-rational type contractive mappings. Fixed Point Theory and Applications, 2015(art.number:97). Available at: https://doi.org/10.1186/s13663-0 15-0332-3.

Banach, S. 1922. Sur les opérations dans les ensembles abstraits et leur applications aux équations intégrales. Fundamenta Mathematicae, 3, pp.133-181 (in French). Available at: https://doi.org/10.4064/fm-3-1-133-181.

Budhia, L., Kir, M., Gopal, D. \& Kiziltunc, H. 2017. New fixed point results in rectangular metric space and application to fractional calculus. Tbilisi Mathematical Journal, 10(1), pp.91-104 [online]. Available at: http://tcms.org.ge/Journals/TMJ Nolume10/Volume10_1/Abstract/abstract10_1_6.html [Accessed: 15 November 2020].

Collaco, P. \& Silva, J.C.E. 1997. A complete comparison of 25 contraction conditions. Nonlinear Analysis: Theory, Methods \& Applications, 30(1), pp.471-476. Available at: https://doi.org/10.1016/S0362-546X(97)00353-2.

Ćirić, Lj. 2003. Some Recent Results in Metrical Fixed Point Theory. Belgrade: University of Belgrade.

Kadelburg, Z. \& Radenović, S. 2014a. Fixed point results in generalized metric spaces without Hausdorff property. Mathematical Sciences, 8(art.number:125). Available at: https://doi.org/10.1007/s40096-014-0125-6.

Kadelburg, Z. \& Radenović, S. 2014b. On generalized metric spaces: A survey. TWMS Journal of Pure and Applied Mathematics, 5(1), pp.3-13 [online]. Available at: http://www.twmsj.az/Files/Contents\%20V.5,\%20\%20N.1,\%20\%202014/pp.313.pdf [Accessed: 15 November 2020].

Karapınar, E. 2014. Discusion on $\alpha-\psi$ Contractions on Generalized Metric Spaces. Abstract and Applied Analysis, 2014(art.ID:962784). Available at: http: //dx.doi.org/10.1155/2014/962784. 
Karapınar, E., Kummam, P. \& Salimi, P. 2013. On $\alpha-\psi$-Meir-Keeler contractive mappings. Fixed Point Theory and Applications, art.number:94. Available at: https: //doi.org/10.1186/1687-1812-2013-94.

Kirk, W.A. \& Shahzad, N. 2014. Fixed Point Theory in Distance Spaces. Springer International Publishing Switzerland. ISBN: 978-3-319-10927-5.

Mohammadi, B. \& Rezapour, Sh. 2013. On modified $\alpha-\psi$-contractions. Journal of Advanced Mathematical Studies, 6(2), pp.162-166 [online]. Available at: https: //www.fairpartners.ro/upload_poze_documente/files/volumul\%206,\%20no.\%202/1 4_Mohammadi.pdf [Accessed: 15 November 2020].

Radenović, S., Kadelburg, Z., Jandrlić, D. \& Jandrlić, A. 2012. Some results on weakly contractive maps. Bulletin of the Iranian Mathematical Society, 38(3), pp.625-645 [online]. Available at: http://bims.iranjournals.ir/article_229.html [Accessed: 15 March 2018].

Rhoades, B.E. 1977. A comparison of various definitions of contractive mappings. Trans. Amer. Math. Soc., 226, pp.257-290. Available at: https://doi.org/10.1 090/S0002-9947-1977-0433430-4.

Samet, B., Vetro, C. \& Vetro, P. 2012. Fixed point theorem for $\alpha-\psi$-contractive type mappings. Nonlinear Analysis: Theory, Methods \& Applications, 75(4), pp.2154-2165. Available at: https://doi.org/10.1016/j.na.2011.10.014.

Salimi, P., Latif, A. \& Hussain, N. 2013. Modified $\alpha-\psi$-contractive mappings with applications. Fixed Point Theory and Applications, art.number:151. Available at: https://doi.org/10.1186/1687-1812-2013-151.

\section{ПРИМЕЧАНИЯ К НЕКОТОРЫМ РЕЗУЛЬТАТАМ В ОБЛАСТИ НЕПОДВИЖНЫХ ТОЧЕК В ПРЯМОУГОЛЬНЫХ МЕТРИЧЕСКИХ ПРОСТРАНСТВАХ, С ИХ ПРИМЕНЕНИЕМ В ХИМИИ}

Мудасир Йоунис ${ }^{\text {, }, ~ Н и к о л а ~ Ф а б и а н о б ~}{ }^{\circ}$ Заид М. Фадаил", Зоран Д. Митровичг, Стоян Н. Раденович ${ }^{\not}$

а Университетский технологический институт - RGPV, кафедра прикладной математики, г. Бхопал, М.П, Индия

${ }^{\sigma}$ независимый исследователь, г. Рим, Италия

в Дамарский университет, педагогический факультет, кафедра математических наук, г. Дамар, Йеменская Республика

г Университет в г. Баня-Лука, электротехнический фракультет, г. Баня-Лука, Республика Сербская, Босния и Герцеговина, корреспондент,

А Белградский университет, Машиностроительный факультет, г. Белград, Республика Сербия

\section{7}


РУБРИКА ГРНТИ: 27.00.00 МАТЕМАТИКА:

27.25.17 Метрическая теория функций, 27.33.00 Интегральные уравнения, 27.39.29 Приближенные методы функционального анализа

ВИД СТАТЬИ: оригинальная научная статья

Резюме:

Введение/цель: В данной статье обсуждаются, суммируются и улучшаются недавние результаты о неподвижных точках в прямоугольных метрических пространствах. Целью данной статьи является представление гораздо более простых и коротких доказательств некоторых новых результатов в области прямоугольных метрических пространств.

Методы: В статье применены стандартные методы теории неподвижной точки в обобщенных метрических пространствах.

Результаты: Полученные результаты данного исследования улучшают известные результаты существующей литературы. Благодаря новому подходу доказана последовательность Коши-Пикара в прямоугольных метрических пространствах. Полученные результаты также используются для доказательства экзистенциальных решений некоторых нелинейных задач, относящихся к химическим наукам. В конце статьи задается открытый вопрос в связи с обобщенными сжатыми отображениями в прямоугольных метрических пространствах.

Выводы: В статье приведены новые результаты, касающиеся теории неподвижных точек в прямоугольных метрических пространствах, примененные в решении некоторых проблем в области химических наук.

Ключевые слова: неподвижная точка, прямоугольное метрическое пространство, сжатое отображение, фрункция Грина. 


\section{НАПОМЕНЕ О НЕКИМ РЕЗУЛТАТИМА О НЕПОКРЕТНИМ}

ТАЧКАМА У ПРАВОУГАОНИМ МЕТРИЧКИМ ПРОСТОРИМА СА ПРИМЕНАМА У ХЕМИЈИ

Мудасир Јоунис ${ }^{\text {, }}$ Никола Фабианоб ${ }^{6}$ Заид М. Фадаил ${ }^{\text {, }}$ Зоран Д. Митровићг, Стојан Н. Раденовићд

а Универзитетски институт за технологију - РГПВ,

Одељење за примењену математику, Бопал, М. П, Индија

${ }^{\sigma}$ независни истраживач, Рим, Италија

в Универзитет Тамар, Педагошки фракултет,

Одељење за математичке науке, Тамар, Република Јемен

г Универзитет у Бањој Луци, Електротехнички фракултет,

Бања Лука, Република Српска, Босна и Херцеговина,

аутор за преписку

д Универзитет у Београду, Машински факултет,

Београд, Република Србија

ОБЛАСТ: математика

ВРСТА ЧЛАНКА: оригинални научни рад

Сажетак:

Увод/циљ: У овом раду се разматрају, уопштавају и побољшавају недавни резултати о непокретним тачкама у оквиру правоугаоних метричких простора. Циљ овог рада је да пружи много једноставније и краће доказе о неким новим резултатима у правоугаоним метричким просторима.

Memode: Користе се стандардне методе из теорије непокретне тачке у генерализованим метричким просторима.

Резултати: Добијени резултати побољшавају добро познате резултате у литератури. Користећи нови приступ доказује се да је Пикаров низ Кошијев у оквиру правоугаоних метричких простора. Добијени резултати користе се за доказ егзистенције решења неких нелинеарних проблема који се примењују у хемијским наукама. На крају се даје једно отворено питање за генерализована контрактивна пресликавања у правоугаоним метричким просторима.

Закључак: Дати су нови резултати за непокретне тачке у правоугаоним метричким просторима са применом на неке проблеме у хемијским наукама.

Кључне речи: непокретна тачка, правоугаони метрички простор, контрактивно пресликавање, Гринова фрункција.

\section{9}


Paper received on / Дата получения работы / Датум пријема чланка: 21.11.2020. Manuscript corrections submitted on / Дата получения исправленной версии работы / Датум достављања исправки рукописа: 29.12.2020.

Paper accepted for publishing on / Дата окончательного согласования работы / Датум коначног прихватања чланка за објављивање: 31.12.2020.

(C) 2021 The Authors. Published by Vojnotehnički glasnik / Military Technical Courier (http://vtg.mod.gov.rs, http://втг.мо.упр.срб). This article is an open access article distributed under the terms and conditions of the Creative Commons Attribution license (http://creativecommons.org/licenses/by/3.0/rs/).

(c) 2021 Авторы. Опубликовано в "Военно-технический вестник / Vojnotehnički glasnik / Military Technical Courier" (http://vtg.mod.gov.rs, http://втг.мо.упр.срб). Данная статья в открытом доступе и распространяется в соответствии с лицензией "Creative Commons" (http://creativecommons.org/licenses/by/3.0/rs/).

(c) 2021 Аутори. Објавио Војнотехнички гласник / Vojnotehnički glasnik / Military Technical Courier (http://vtg.mod.gov.rs, http://втг.мо.упр.срб). Ово је чланак отвореног приступа и дистрибуира се у складу са Creative Commons лиценцом (http://creativecommons.org/licenses/by/3.0/rs/). 